\title{
Investigating the impact of process and product innovation strategies on business performance due to the mediating role of environmental dynamism using structural equations modeling
}

\author{
Hamed Zand ${ }^{1}$, Babak Rezaei ${ }^{1}$
}

${ }^{1}$ Islamic Azad University, North Tehran Branch, Department of Industrial Management, Tehran, Iran.

How to cite: Zand, H. and Rezaei, B. (2020), "Investigating the impact of process and product innovation strategies on business performance due to the mediating role of environmental dynamism using structural equations modeling", Brazilian Journal of Operations \& Production Management, Vol. 17, No. 2, e2020921. https://doi.org/10.14488/10.14488/BJOPM.2020.022

\section{ABSTRACT}

Goal: the main purpose of the present study was to investigate the impact of process and product innovation strategies on business performance due to the dynamic environmental mediator role.

Design / Methodology / Approach: The research method was based on purpose of applied research and in terms of data collection and analysis method was survey-correlation. The statistical population of this study consisted of 36 managers of Iranian banking industry. Questionnaires were used for data collection. Structural equation modeling was used to analyze the data.

Results: the results showed that process and product innovation strategies have a positive and significant effect on business performance. Also, Sobel test results indicated that at $95 \%$ confidence level, process and product innovation strategies through dynamic mediator variable. Environment has a positive and significant impact on business performance.

Limitations of the investigation: Since the present study is an exploratory study, the findings of the study are limited to the sample size and the results may change if the sample size is changed, Also the existence of different views on the topic of research among members of the statistical community can influence the results of the research to some extent.

Practical implications: The research findings can be used to improve the business performance of companies active in the banking industry through the implementation of innovation strategies.

Originality / Value: The product innovation strategies are more visible than process innovation strategies so that the customers can easily feel their presence and this kind of innovation creates a situation where the organization can create a new market for its business.

Keywords: Process Innovation Strategy; Product Innovation Strategy; Business Performance; Environmental Dynamism; Structural Equations Modeling.

\section{1- INTRODUCTION}

Environmental uncertainty, competition, complexity, globalization, and process and technology changes in international markets play a major role in an organization's performance, while the most important concern for organizations is to formulate and implement strategies that can guarantee the performance of organizations in the competitive conditions of international markets (Felipe et al., 2020). The main reason for the stagnation of

Financial support: None.

Conflict of interest: The authors have no conflict of interest to declare.

Corresponding author: hamed.zand2019@gmail.com

Received: 29 Jan 2020

Approved: 9 May 2020

Editor: Osvaldo L. G. Quelhas. 
Investigating the impact of process and product innovation strategies on business performance due to the mediating role of environmental dynamism using structural equations modeling

companies and their low performance is their failure to use innovation strategies (Jansen et al., 2006). In the field of production, Prajogo (2016) believes that an organization can succeed that regularly uses innovation strategies, according to the market situation to overcome the competition and uncertainty resulting from the turmoil in the international markets. Also based on the findings Wu et al. (2017) and Zhu et al. (2019) new product development is crucial for firms to survive and improve innovation performance in the current fast-changing business environment. In international markets where companies are facing a severe decline in performance, organizations need to move forward reducing the time of development of new and innovative products (product innovation) and providing optimal methods of manufacturing products and services (process innovation) as tools to achieve long-term success and competitive advantages (Şahin and Gürbüz, 2020). The concept of innovation is tied to the notions of environmental changes and competition and innovation will practically lose its meaning without these components. Therefore, in the current competitive environment, the main concern of organizations, particularly in the private sector, is to penetrate the market and maintain the competitive position competitiveness by means of innovation strategies, implementing them and the process of using these strategies in international markets for better business performance (Gallouj and Windrum, 2009). Innovation has become so important nowadays that many companies collaborate with each other globally on the path to create innovation (Weiblen and Chesbrough, 2015). A review of research done in the field of organizational innovation shows that most studies on innovation have focused on understanding the impacts of inter-organizational factors such as the organization's senior management and human resources management on the innovation (Murat Ar and Baki, 2011). This is due to the fact that innovation is seen as an organizationcontrolled activity and the impact of external factors such as environmental changes on innovation is rarely considered. Nowadays, innovative actions and activities of organizations, including measures made in the area of processes and products, are directed under the influence of external factors such as customers' demand, competitors' behavior, technology changes, and government regulations (Tao et al., 2010). As a concept, innovation has different dimensions that innovation in process is one of the important ones.

Innovation can be a valuable tool for social and environmental issues during corporate operations (Vafaei et al., 2019). Innovation in process is defined as the improvement of the processing technologies required to produce a product; but as this type of innovation occurs within the organization, it is less recognized (Weiss, 2003). Product innovation is defined as the use of new equipment, features and technology to produce new products (Carranza, 2010). Previous studies have confirmed the impact of these two dimensions of innovation on the business performance. It should be noted, however, that the impact of organization's environmental conditions can influence this impact and alter its level. Also, the context of the environment in which the company operates is crucial in this regard (Tsai and Yang, 2013). Under these circumstances, managers need to develop organizational innovation strategies based on environmental conditions and seek a proportionality since changes in the external environment of an organization can change the influence rate of the organization's innovation strategies on improving the business performance. Numerous studies have been done so far on the moderating and adjustment effect of business environment on the companies' performance (García-Villaverde et al., 2020). In this regard, the studies by Damanpour (2010), Jayaram et al. (2014), Prajogo (2016) and Zeng et al. (2019) can be mentioned. Globalization and the dramatic technological changes in the present era have made the path of banking developments inside Iran not different from the path that other countries in the world are taking in this field. Banks active in the Iranian banking industry, like any other country, need innovative capabilities in order to be successful in the banking industry and gain more market share. Of course, besides paying attention to product and process innovation, environmental impacts need to be addressed. One of the most important environmental impacts is the environmental dynamics that lead to constant changes and need to be constantly monitored. This study was designed to examine the relationship between process and product innovation 
strategies and business performance due to the mediating role of environmental dynamism variable in Iran's banking industry. The difference between the present study and previous research is to examine process innovation strategies in addition to evaluating the product innovation strategies. Also, in this study, the environmental dynamism variable was studied as a mediator variable. In fact, the present study sought to answer that question that whether does the environmental dynamism variable play a mediating role in the influence of process and product innovation strategies on the business performance of banks active in Iran's banking industry and process and product innovation strategies affect business performance through the environmental dynamism variable. By answering this question, the research gap in examining the impact of innovation strategies on business performance of banks active in Iran's banking industry will disappear due to the mediating role of environmental dynamism.

\section{- $\quad$ Process innovation strategy and business performance}

Process innovations may also include inputs, job characteristics, workflow, and information (Kanyangi and Gichinga, 2019). In the case of a variety of process innovations, it is appropriate to consider that a process actually involves what thins, which, in turn, may provide a better view of process innovation. The key feature of innovation of process is that this type of innovation is within the organization and happens on the production line and is not visible to people outside the organization and it's a unique feature since it is inside the organization, which cannot be seen and imitated by competitors (Maine et al., 2012). Businesses with a process innovation strategy do not behave aggressively with the market and consider lower prices and better production (Ittner and Larcker, 1997). The businesses that choose the process innovation strategy as their strategy create barriers for the entry of their competitors into today's international competitive markets where imitation is very high (Porter, 1985). By implementing the process innovation strategy in businesses, the corporate profits will increase as the costs of business decrease. A price drop will make customers more likely to buy this commodity as similar products have a higher price; in this case, it will lead both to increase the company's profits and to bring a greater market share for the business, and finally, will improve the business performance (Klingenberg et al., 2013). Corporations in the banking industry, like other industries, need to implement process innovation strategies in their organizational structure so that they can offer new and diverse services to their customers and increase their profitability (Zhao et al., 2019). Accordingly, the first and the third hypotheses of the research will be as follows:

$\mathrm{H1}$ : The innovation in process strategy has a significant and positive impact on the environmental dynamism.

H3: The innovation in process strategy has a significant and positive impact on the business performance.

\section{- $\quad$ Product innovation strategy and business performance}

As a common process in various sectors of the industry, innovation provides fundamental opportunities for organizations to enter new markets and eliminate stagnation. The types of innovation strategies are divided into two categories of product strategies and process strategies (Organization for Economic Co-operation and Development, 1997). A review of previous research shows that the product innovation strategies lead to the increased competitive advantages, reduced production costs, and the creation of a competitive advantage in the performance of organizations. The use of software and hardware tools is very influential in the path of product innovation (Kohler, 2015). The product innovation strategy is very seeming and customers can easily feel its presence. This kind of innovation is capable of creating a new market for business and improving the business performance (Damanpour, 2010). According to a research by Tsai and Yang (2013) on the impact of 
innovation strategy on business performance, the product innovation strategy was found to have a positive impact on the organizational performance. The results of studies by Prajogo (2016) and Zhang et al. (2019) revealed that the product innovation strategies influence the business performance. The results of Armanios et al. (2017) research also proved that innovation strategies in product improve the business performance and ultimately will lead to the survival of the organization in the competitive conditions. Implementing innovations in the banking industry's products and services can have many benefits, including boosting financial flow and ultimately bank profitability. For example, the introduction of automated banking services such as ATMs in the 1960 s promoted an innovative product of banks' financial performance) Barberis (2014). Accordingly, the second and the fourth hypotheses of the research will be as follows:

$\mathrm{H} 2$ : The innovation in product strategy has a significant and positive impact on the environmental dynamism.

H4: The innovation in product strategy has a significant and positive impact on the business performance.

\section{- Environmental dynamism and business performance}

In dynamic environments, companies strive to be innovative in the production and the provision of their products and services. Paying attention to innovation in a dynamic environment helps organizations respond to the customers' needs and priorities and thereby create a competitive advantage for themselves (Lumpkin and Dess, 2001). The organization's innovation strategies are defined and formulated to improve business performance; however, the effectiveness of these strategies depends on several factors, including the business environment conditions (Prajogo, 2016). The study of Jansen et al. (2006) demonstrated that factors such as competition and environmental dynamism have a moderating effect on the relationship between different types of services innovation orientations and the financial performance of the organization. According to the research, dynamic environments provide the conditions for organizations to move towards creating innovation. Under these conditions, one can say environmental dynamism plays a driving role (Wang and Chen, 2010; Lee, 2011). The customers' tastes and demands change rapidly in dynamic environments and organizations must respond to these changes by adopting innovation in their products (Tripsas, 2008). This demonstrates the importance of adopting innovative strategies in the organizational products and processes. The rapid response of companies to environmental change using innovative strategies leads to improved business performance and the company can gain more profits accordingly. The corporate performance refers to the extent of the firm's activities over a given period of time, leading to an income, profit or an increase in the shareholders' wealth (Allen and Helms, 2006). In different industries, including banking, due to the continual shifts in customer preferences, banks need to change their attitudes towards environmental outcomes so that they have to understand the impact of environmental dynamics and adopt appropriate strategies (Keramati et al., 2012). Accordingly, the fifth hypothesis of the research will be as follows:

H5: Environmental dynamism has a significant and positive impact on the business performance.

\section{- $\quad$ Research hypotheses and conceptual model}

According to the research objective, i.e., examining the impact of process and product innovation strategies on business performance due to the mediating role of environmental dynamism, the research hypotheses are as follows: 
a. H1: The innovation in process strategy has a significant and positive impact on the environmental dynamism.

b. H2: The innovation in product strategy has a significant and positive impact on the environmental dynamism.

c. H3: The innovation in process strategy has a significant and positive impact on the business performance.

d. H4: The innovation in product strategy has a significant and positive impact on the business performance.

e. H5: Environmental dynamism has a significant and positive impact on the business performance.

f. H6: The innovation in process strategy has a significant and positive impact on the business performance through environmental dynamism.

g. H7: The innovation in product strategy has a significant and positive impact on the business performance through environmental dynamism.

The research conceptual model based on the research hypotheses is shown in Figure 1, in which, the variables of product innovation strategy and process innovation strategy are considered as the independent variables, while environmental dynamism and business performance are seen as the mediator variable and the dependent variable, respectively.

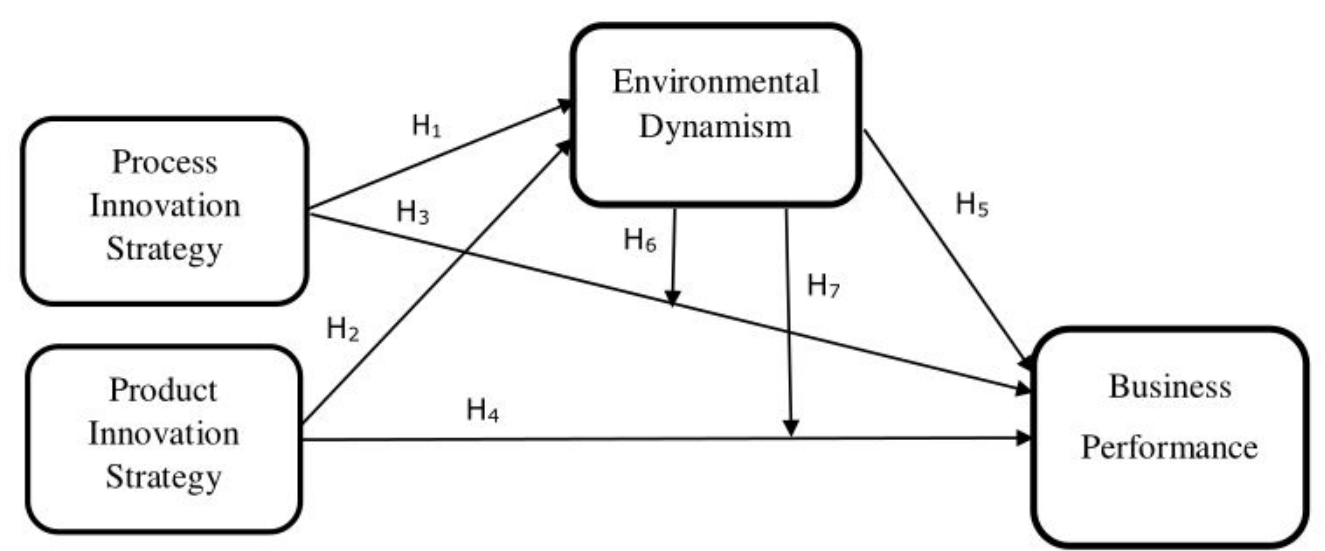

Figure 1: The research conceptual model (Adapted from Prajogo, 2016)

\section{2- MATERIAL AND METHODS}

Given that in the present study, we investigated and analyzed the relationship between innovation strategies and business performance considering the mediating role of environmental dynamism, this was an applied study in terms of objective. Also, as we used the questionnaire tool in this research in trying to evaluate the extent and type of relationships between variables to answer a real-world scientific problem, therefore, this research was a surveying type in terms methodology. The study statistical population consisted of 36 managers of banking industry in Iran. These executives were those with a good work experience and at least a master's degree, and also had sufficient experience in implementing and streamlining innovation in the banking industry. The reason for the choice of 36 managers as the statistical population is that 36 banks are operating in the banking industry and the top executives of these banks, all of which are 36, were selected as members of the statistical community. Due to the small size of the statistical population, the sample size was considered to be equal to the size of the statistical population. In fact, the sampling method will be the census method due to the small size of the sample. In this study, a questionnaire was used to collect data to test the research hypotheses. The research questionnaire was distributed 
among the members of the statistical sample in two forms: face-to-face and e-mail. The questionnaire used in this study was derived from the study of Prajogo (2016) and the questions contained in the questionnaire are scored based on a five-option Likert scale. In this questionnaire, the process innovation strategies variable with 4 items, the product innovation strategies variable with 4 items, the business performance variable with 3 items, and the environmental dynamism variable with 5 items were evaluated. The questionnaire items are shown in Table 1.

Table 1. Questionnaire Scales and items (Adapted from Prajogo, 2016)

\begin{tabular}{|c|c|}
\hline Scales & Items \\
\hline \multirow{5}{*}{$\begin{array}{l}\text { Process innovation } \\
\text { strategy }\end{array}$} & We improve the reliability of our production processes and technologies \\
\hline & We improve the speed and efficiency of our production \\
\hline & $\begin{array}{c}\text { processes } \\
\end{array}$ \\
\hline & We use advanced technologies in our production processes \\
\hline & $\begin{array}{l}\text { We strive to keep our production processes ahead of } \\
\text { competitors }\end{array}$ \\
\hline \multirow{4}{*}{$\begin{array}{l}\text { Product innovation } \\
\text { strategy }\end{array}$} & We develop or use new components \\
\hline & We develop or use new materials \\
\hline & We develop or use new technologies in our products \\
\hline & We develop or use new product features \\
\hline \multirow{3}{*}{$\begin{array}{l}\text { Business } \\
\text { performance }\end{array}$} & Our organizational unit has relatively strong competitors \\
\hline & Competition in our market is extremely high \\
\hline & Competition in our market is intense \\
\hline \multirow{5}{*}{$\begin{array}{l}\text { Environmental } \\
\text { dynamism }\end{array}$} & Environmental changes in our market are intense \\
\hline & Our clients regularly ask for new products and services \\
\hline & In our market, changes are taking place continuously \\
\hline & In a year, our market has changed significantly \\
\hline & $\begin{array}{l}\text { In our market, the volumes of products and services to be delivered change } \\
\text { fast and often }\end{array}$ \\
\hline
\end{tabular}

The face and content validities of the research questionnaire were confirmed by reviewing the opinions of banking management experts and the business field scholars. They had enough experience and expertise. Formal validity is a kind of objective judgment about the structure of the research instrument (questionnaire) with the qualitative approach as the first step of validity assessment and indicates the reasonableness of a test by the experts. The validity of questionnaire constructs was assessed by confirmatory factor analysis technique and the significance of the items related to the target constructs was confirmed, which results are presented in Table 1. Also, Cronbach's alpha coefficient was used to examine the reliability of the questionnaire and internal consistency of the instruments used. The results of this test showed that all values are above 0.7 ; thus, we could deduce that the research tool (questionnaire) has the required reliability. The results of this evaluation are reported in Table 2. For data analysis, we used the structural equations modeling method to examine the fitting of the structural equations modeling and test the research hypotheses. The relevant analyses were made in Smart PLS.3 software. The most important reasons for using SEM-PLS include non-normal data, small sample size and formative measures (Hair et al., 2012). Due to the small sample size, this method was used in the present study.

In this study, the structural equations modeling with the partial least squares approach was used to analyze the research model. The algorithm consists of two main steps:

1. Examining the fit of the model

2. Testing the research hypotheses

The first part, namely, examining the model fit is done in three parts: 
1. Fitting the measurement models

2. Fitting the structural model

3. Overall fitting of the model

Thus, using reliability and validity criteria, the accuracy of the relationships in the measurement models was initially ensured. Then, the relationships in the structural section were explored. Finally, the overall fitting of the research model was investigated.

- $\quad$ The measurement models fitting

The fitting of the measurement models involves evaluating the reliability and validity of the research constructs. Fornell and Larcker (1981) proposed three criteria for evaluating the reliability of constructs:

1. The reliability of each of the research items.

2. The combined reliability of each of the research constructs.

3. The Average Variance Extracted (AVE) or the same convergent validity.

According to the structural equations modeling algorithm, three criteria of reliability, convergent validity, and divergent validity were used to evaluate the fitness of measurement models.

1. Reliability: Reliability is assessed through three measuring factor loadings, Cronbach's alpha, and the combined reliability.

The factor load is a numerical value that measures and determines the severity of the relationship between a hidden variable (construct) and the relevant apparent variable (index) during the path analysis process. The greater the value of the factor loading of an index in relation to a given construct, a greater contribution of that index would be in explaining that construct.

Cronbach's alpha is a measure to assess reliability and an appropriate measure for internal consistency. Internal consistency indicates the degree of correlation between a construct and its related indices. The criterion for the suitability of the Cronbach's alpha is at least 0.7 , However, some sources consider the value of 0.6 sufficient.

Combined reliability was introduced by Werts et al. (1974). The superiority of this criterion over the Cronbach's alpha coefficient is that the reliability of the constructs is not calculated not absolutely but due to the correlation of their constructs with each other. A combined reliability value above 0.7 for each construct indicates good internal consistency for the measurement models, while a value less than 0.6 indicates no reliability.

2. Validity: In the method of modeling the structural equations, the validity criterion is examined through two methods of convergent validity and divergent validity. Convergent Validity: After examining the three reliability criteria, the convergent validity is the second criterion of the measurement models fitting. The convergent validity criterion indicates the mean of the variance shared between each construct with its indices and a value of 0.4 and higher of this criterion is considered appropriate.

Divergent Validity: The third criterion for measuring the fit of measurement models in PLS analyzes is divergent validity, which was examined in this study by the proposed method of Fornell Larker. According to the Fornell and Larcker (1981) method, the divergent validity is 
Investigating the impact of process and product innovation strategies on business performance due to the mediating role of environmental dynamism using structural equations modeling

confirmed if the squared mean variance extracted for each construct is greater than the correlation between the constructs. In this method, this issue is examined by a matrix, which cells contain the values of the correlation coefficient between the constructs and the square root of the convergent validity values of each construct.

\section{3-RESULTS}

As mentioned in the previous section, two main criteria of validity and reliability were used in this study to evaluate the appropriateness of measurement models. The results of these criteria are presented in Table 2. Given that the values obtained with respect to the reliability criterion of the research constructs are higher than 0.7 , it can be concluded that the measurement models have good internal consistency. also the convergent validity criteria result show that the obtained values are all above the 0.4 use thus it can be said that the research constructs are of acceptable convergent validity. Concerning the divergent validity criterion, the results of Table 3. show that the original diameter of the matrix is greater than the correlation value between them in the low core diameter cells, therefore, it can be said that in the present study, the structural model correlates more with their indices than with other structures. In other words, the divergence validity of the model is appropriate.

Table 2. The results of factor loadings and quality criteria of measurement models

\begin{tabular}{|c|c|c|c|c|c|c|c|}
\hline Construct & Question & $\begin{array}{l}\text { Factor } \\
\text { loading }\end{array}$ & $\begin{array}{c}\text { Cronbach's } \\
\text { alpha }\end{array}$ & $\begin{array}{l}\text { Combined } \\
\text { reliability }\end{array}$ & $\begin{array}{c}\text { Convergent } \\
\text { validity }\end{array}$ & $\begin{array}{l}\text { Shared } \\
\text { values }\end{array}$ & $\begin{array}{c}\text { Redundancy } \\
\text { values } \\
\end{array}$ \\
\hline \multirow{4}{*}{$\begin{array}{l}\text { Process } \\
\text { Innovation } \\
\text { Strategy }\end{array}$} & PIS1 & 0.719 & \multirow{4}{*}{0.816} & \multirow{4}{*}{0.778} & \multirow{4}{*}{0.492} & \multirow{4}{*}{0.539} & \multirow{4}{*}{0.000} \\
\hline & PIS2 & 0.840 & & & & & \\
\hline & PIS3 & 0.724 & & & & & \\
\hline & PIS4 & 0.806 & & & & & \\
\hline \multirow{4}{*}{$\begin{array}{l}\text { Product } \\
\text { Innovation } \\
\text { Strategy }\end{array}$} & PIS5 & 0.559 & \multirow{4}{*}{0.835} & \multirow{4}{*}{0.781} & \multirow{4}{*}{0.476} & \multirow{4}{*}{0.421} & \multirow{4}{*}{0.000} \\
\hline & PIS6 & 0.779 & & & & & \\
\hline & PIS7 & 0.625 & & & & & \\
\hline & PIS8 & 0.769 & & & & & \\
\hline \multirow{5}{*}{$\begin{array}{c}\text { Environmental } \\
\text { Dynamism }\end{array}$} & END1 & 0.623 & \multirow{5}{*}{0.888} & \multirow{5}{*}{0.794} & \multirow{5}{*}{0.528} & \multirow{5}{*}{0.459} & \multirow{5}{*}{0.200} \\
\hline & END2 & 0.388 & & & & & \\
\hline & END3 & 0.782 & & & & & \\
\hline & END4 & 0.583 & & & & & \\
\hline & END5 & 0.386 & & & & & \\
\hline \multirow{3}{*}{$\begin{array}{l}\text { Business } \\
\text { Performance }\end{array}$} & BUP1 & 0.809 & \multirow{3}{*}{0.806} & \multirow{3}{*}{0.789} & \multirow{3}{*}{0.556} & \multirow{3}{*}{0.529} & \multirow{3}{*}{0.267} \\
\hline & BUP2 & 0.776 & & & & & \\
\hline & BUP3 & 0.642 & & & & & \\
\hline
\end{tabular}

Table 3. Divergent validity results

\begin{tabular}{ccccc}
\hline Construct & $\begin{array}{c}\text { Process } \\
\text { Innovation } \\
\text { Strategy }\end{array}$ & $\begin{array}{c}\text { Product } \\
\text { Innovation } \\
\text { Strategy }\end{array}$ & $\begin{array}{c}\text { Environmental } \\
\text { Dynamism }\end{array}$ & $\begin{array}{c}\text { Business } \\
\text { Performance }\end{array}$ \\
\hline Process Innovation Strategy & 0.701 & & & \\
\hline Product Innovation Strategy & 0.551 & 0.689 & & \\
\hline Environmental Dynamism & 0.649 & 0.612 & 0.726 & 0.745 \\
Business Performance & 0.634 & 0.599 & 0.667 & \\
\hline
\end{tabular}

\section{- $\quad$ Fitting the structural model}

In the structural equations modeling method, after fitting the measurement models, the fitting of the structural model of the research is investigated. In analyzing the structural model, 
the relationships between hidden variables (constructs) with each other are analyzed and the criteria of significance coefficients $t$, the coefficient of determination or the same, $\mathrm{R}^{2}$, and the redundancy criterion are used to fit the model. The significance $t$ values are used to evaluate the fitting of the research structural model by several criteria that the first and most basic criteria are significance coefficients $t$, or the same $t$-values. The values of $t$ greater than 1.96 indicate the accuracy of relationships between the constructs, and as a result, the research hypotheses are confirmed at 95\% confidence level. In Figure 2, the t values to evaluate the structural part of the model are shown. According to the results, all the numbers on the paths are higher than 1.96. This indicates that the paths are significant, the structural model is fit, and the research hypotheses are validated. The second criterion necessary for measuring the structural model fit is to determine the coefficients of determination, or the same $\mathrm{R}^{2}$ related to the endogenous hidden variables (dependent variable) of the model. This criterion is used to connect the measurement and structural components of the structural equations modeling and represents the effect of an exogenous (independent) variable on an endogenous (dependent) variable. It should be noted that the $R^{2}$ values of the model are calculated only for the endogenous constructs of the model the value of this criterion is zero for the exogenous constructs of the model. Chin (2010) introduced three values of $0.19,0.33$, and 0.67 as weak, moderate, and strong criteria of $R^{2}$ criterion. The values of $R^{2}$ can be seen in Figure 3. Given that the value of $R^{2}$ is calculated for environmental dynamism and business performance constructs, considering the three criteria values, the suitability of the structural fit is confirmed.

\section{- Redundancy criterion}

This criterion is obtained by multiplying the shared values of the constructs by their $\mathrm{R}^{2}$ values, which indicates the variability rate of the indices of an endogenous (dependent) construct influenced by one or more exogenous (independent) constructs. The mean redundancy index is a general measure of the quality of the structural model that applies to all endogenous constructs and is only calculated for use in the calculation formula of the overall model fitting and index of goodness of fit. The results of this criterion are presented in Table 1, indicating the high and acceptable fit of the structural model.

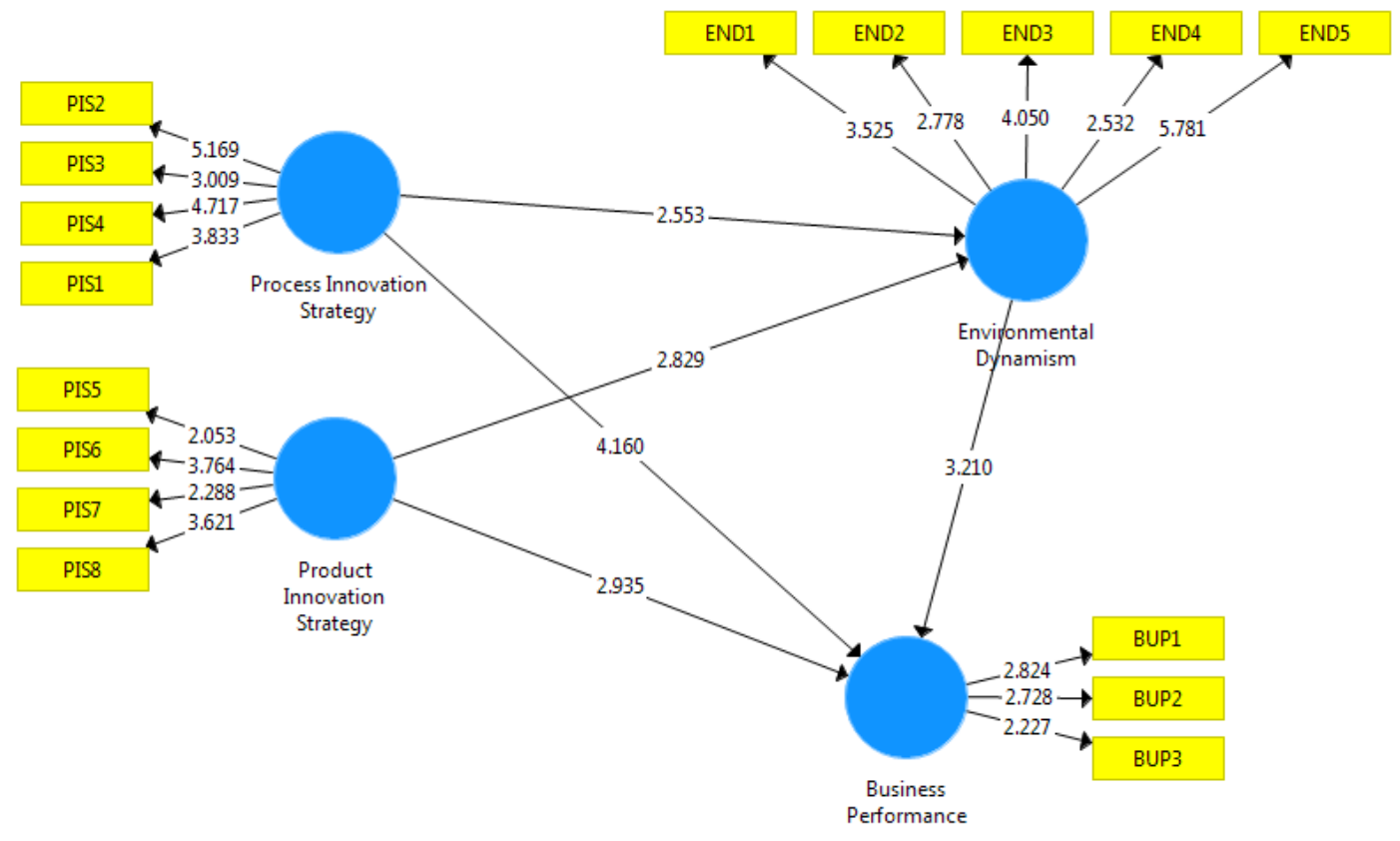

Figure 2. The t-Values 


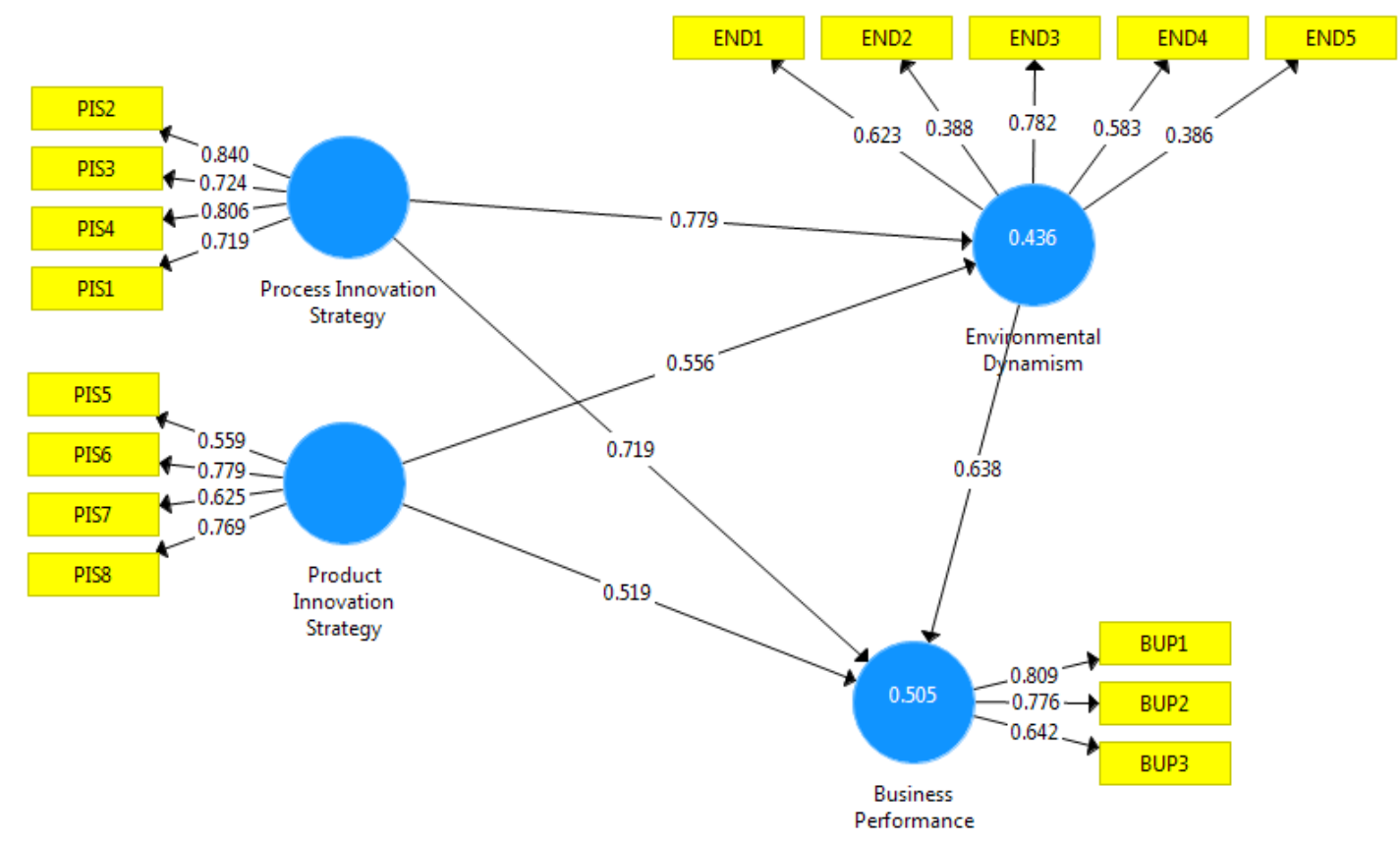

Figure 3. The values of path coefficients, factor loadings, and $R^{2}$

- $\quad$ Fitting the general model of research

The GOF (Goodness of Fit) criterion was used to evaluate the fit of the overall model, which controls both the measurement and structural model components. This criterion was introduced by Tenenhaus et al. (2004) and is calculated according to the following equation:

$\mathrm{GOF}=\sqrt{\text { average }(\text { Communality }) \times \text { averageR } 2}$

is criterion is defined by three values of $0.01,0.25$, and 0.36 as weak, moderate and strong values (Wetzels et al., 2009).

$\mathrm{GOF}=\sqrt{0.487 \times 0.470}=0.478$

As can be seen, the GOF criterion value is equal to 0.478 , which, due to the three values of $0.01,0.25$ and 0.36 as weak, moderate, and strong values for GOF, indicates a strong overall model fit.

\section{- $\quad$ Testing the research hypotheses}

In this section, the research hypotheses were tested by examining the significance coefficients (t-values) of each of the paths as well as the path coefficients. If the significance coefficient of each path is greater than 1.96, the corresponding path is significant at $95 \%$ confidence level and the concerning hypothesis is confirmed. The results of testing the $\mathrm{H} 1$ to $\mathrm{H} 5$ hypotheses are reported in Table 4 . The results showed that the first to fifth hypotheses of the research were confirmed. 
Table 4. The results of hypotheses 1 to 5

\begin{tabular}{lccc}
\hline \multicolumn{1}{c}{ Hypothesis } & $\begin{array}{c}\text { Path } \\
\text { Coefficient }\end{array}$ & t-Values & $\begin{array}{c}\text { Test } \\
\text { Result }\end{array}$ \\
\hline $\begin{array}{c}\text { The positive impact of process innovation strategy on } \\
\text { environmental dynamism }\end{array}$ & 0.779 & 2.553 & Confirmed \\
\hline $\begin{array}{c}\text { The positive impact of product innovation strategy on } \\
\text { environmental dynamism }\end{array}$ & 0.556 & 2.829 Confirmed \\
\hline $\begin{array}{c}\text { The positive impact of process innovation strategy on the } \\
\text { business performance }\end{array}$ & 0.719 & $4.160 \quad$ Confirmed \\
\hline $\begin{array}{c}\text { The positive impact of product innovation strategy on the } \\
\text { business performance }\end{array}$ & 0.519 & 2.935 Confirmed \\
The positive impact of environmental dynamism on business \\
performance
\end{tabular}

We should note that in the sixth and seventh hypotheses, the mediating role of variable environmental dynamism was examined in relation to the product and process innovation strategies and business performance. The Sobel and VAF tests were used to test these hypotheses.

- $\quad$ Testing the hypotheses with the mediating variable

The Sobel test is used to examine the significant effect of a mediator variable on the relationship between two independent and dependent variables, and if its value at $95 \%$ confidence level is greater than 1.96, it indicates the significance of the mediator variable effect in this relation. In addition to the Sobel test used to examine the significance of the mediating effect of a variable, the VAF statistic can also be used to determine the severity of the effect, which is a value between 0 and 1 , and the closer its value to 1 , the greater the effect of the mediator will be indicated (Preacher and Leonardelli, 2003). In the Sobel test, a Z value is obtained by the following equation.

$$
Z-\text { Value }=\frac{a \times b}{\sqrt{\left(b^{2} \times S_{a}^{2}\right)+\left(a^{2} \times S_{b}^{2}\right)+\left(S_{a}^{2} \times S_{b}^{2}\right)}}
$$

Where,

Parameter a: The path coefficient between the independent variable and the mediator variable

Parameter b: The path coefficient between the mediator variable and the dependent variable Parameter $\mathrm{S}_{\mathrm{a}}$ : The standard error of the independent and mediator variables path

Parameter $S_{b}$ : The standard error of the mediator and dependent variables path

Hypothesis $6 \frac{(0.779 \times 0.638)}{\sqrt{\left(0.638^{2} \times 0.289^{2}\right)+\left(0.779^{2} \times 0.112^{2}\right)+\left(0.289^{2} \times 0112^{2}\right)}}=\frac{0.4970}{0.0424}=11.72$

Hypothesis $7 \frac{(0.556 \times 0.638)}{\sqrt{\left(0.638^{2} \times 0.175^{2}\right)+\left(0.556^{2} \times 0.233^{2}\right)+\left(0.175^{2} \times 0.233^{2}\right)}}=\frac{0.3547}{0.0308}=11.51$

According to the results of Sobel test, one can conclude that at 95\% confidence level, the impact of the mediating variable of environmental dynamism on the relationship between process innovation strategy and product innovation strategy with the business performance 
is significant and positive and the sixth and seventh hypotheses are confirmed by the test values of 11.72 and 11.51, respectively. In fact, this result shows that the process innovation and product innovation strategies have a positive and significant impact on the business performance through environmental dynamism variable.

VAF test: The value of this test is obtained by the following relation.

$\operatorname{VAF}=\frac{\mathrm{a} \times \mathrm{b}}{(\mathrm{a} \times \mathrm{b})+\mathrm{c}}$

Where,

a: The value of the path coefficient between independent and mediator variables

b: The value of the path coefficient between dependent and mediator variables

c: The value of the path coefficient between dependent and independent variables

o Hypothesis $6=\frac{0.779 \times 0.638}{(0.779 \times 0.638)+0.719}=0.408$

The value of 0.408 means that more than one third of the impact of process innovation strategy on business performance is indirectly explained by the mediator variable of environmental dynamism.

o Hypothesis $7=\frac{0.556 \times 0.638}{(0.556 \times 0.638)+0.519}=0.405$

The value of 0.405 means that more than one third of the impact of product innovation strategy on business performance is indirectly explained by the mediator variable of environmental dynamism.

\section{4- DISCUSSION AND CONCLUSION}

The purpose of the present study was to investigate the impact of process and product innovation strategies on business performance due to the mediator role of the environmental dynamism. In this regard, after reviewing the subject literature and research background, the research hypotheses and conceptual model were defined. The structural equations modeling method was used to fit the research model and test the hypotheses. The results of the first hypothesis testing revealed that the process innovation strategy has a positive and significant effect on the environmental dynamism and the process innovation strategy directly explains $0.779 \%$ of the changes related to the environmental dynamism. Accordingly, one can conclude that formulating innovative strategies in the banking industry processes can affect the environmental dynamism. The results of the second hypothesis testing showed that the product innovation strategy has a positive and significant effect on the environmental dynamism and the product innovation strategy directly explains $0.556 \%$ of changes the changes related to the environmental dynamism. Accordingly, one can conclude that formulating innovative strategies in the production of banking industry products can affect the environmental dynamism. The results of the third hypothesis testing showed that the process innovation strategy has a positive and significant impact on business performance and the process innovation strategy directly explains $0.719 \%$ of changes related to the business performance of banks active in Iran's banking industry. The results of testing this hypothesis were consistent with the findings of Wu et al. (2017), Prajogo (2016) and Klingenberg et al. (2013) and they all confirm the positive impact of process innovation strategy on the business performance. Today, innovation in the Iranian banking industry is of 
Investigating the impact of process and product innovation strategies on business performance due to the mediating role of environmental dynamism using structural equations modeling

great importance for a variety of reasons such as competitive market and resource scarcity. The process innovation strategy is implemented within the organization (bank); thus, this innovation is monopolized by the business, and thereby, improves the business performance of the bank. The results of the fourth hypothesis testing demonstrated that the product innovation strategy has a significant and positive effect on the business performance and the product innovation strategy directly explains $0.519 \%$ of changes related to the business performance of banks active in Iran's banking industry. The results of testing this hypothesis were consistent with those of García-Villaverde et al. (2020), Prajogo (2016) and Damanpour (2010). The product innovation strategies are more visible than process innovation strategies so that the customers can easily feel their presence and this kind of innovation creates a situation where the organization can create a new market for its business. The results of the fifth hypothesis testing indicated that the environmental dynamism in the banking industry has a significant and positive effect on business performance and environmental dynamism directly explains $0.638 \%$ of changes related to business performance of banks active in Iran's banking industry. Given the impact rate of environmental dynamism on the business performance of banks operating in the Iranian banking industry, it seems imperative that industry the executives and decision makers of this industry pay attention to this crucial factor in formulating the business plan and develop the medium-term and long-term plans for the organization based on the degree of environmental variability. The results of the sixth and seventh hypotheses testing indicated that the environmental dynamism variable has a mediating role in the relationship between process innovation and product innovation strategies and process and product innovation strategies have a significant and positive impact on the business performance through the environmental dynamism variable. Accordingly, one can conclude that the ability of any bank to improve its business performance depends on its innovation. On the other hand, the most important factor in banks' indoor environment is to adopt strategies fit to the environment, which is essential to efficiency and effectiveness and ultimately to the productivity. Also, considering the changes occurring in the external environment of the organization and understanding the severity of these changes in different domains, including technology will help managers and decision makers to choose and adopt effective strategies. Therefore, adopting innovative strategies in the organization's products and processes that are adapted to environmental changes will improve, enhance, and develop the business. Based on the results, it is suggested that researchers in future research examine the impact of variables such as environmental competitiveness as a mediating variable in the relationship between innovation strategies and business performance. Considering the environmental dynamics and environmental competitiveness of the relationship between the organization's innovations and the business performance of banks can help bank managers to better study the impact of environmental conditions on their business performance in a competitive market. It is also suggested that researchers in future research study different aspects of organizational innovation capability. Since the present study is an exploratory study, the findings of the study are limited to the sample size and the results may change if the sample size is changed and given that the most important limitation of this research is the small sample size, It is suggested that researchers in future research increase the size of the statistical sample and compare the results with the results of this study.

\section{5-REFERENCES}

Allen, S.R. and Helms, M.M. (2006), "Linking strategic practices and organizational performance to porter's generic strategies", Business Process Management Journal, Vol. 12, No. 4, pp. 433-54.

Armanios, D.E., Eesley, C.E., Li, J. et al. (2017), "How entrepreneurs leverage institutional intermediaries in emerging economies to acquire public resources", Strategic Management, Vol. 38, No. 7, pp. 1373-90. http://dx.doi.org/10.1002/smj.2575.

Barberis, J. (2014), The Rise of Fintech: Getting Hong Kong to Lead the Digital Financial Transition in APAC, Fintech Report, Fintech HK, Hong Kong. 
Carranza, J.E. (2010), "Product innovation and adoption in market equilibrium: the case of digital camera", International Journal of Industrial Organization, Vol. 28, pp. 604-18. http://dx.doi.org/10.1016/j.ijindorg.2010.02.003.

Chin, W.W. (2010), "How to write up and report PLS analyses", in Esposito Vinzi, V., Chin, W.W., Henseler, J. and Wang, H. (Eds.), Handbook of Partial Least Squares: Concepts, Methods and Applications, Springer, Heidelberg, pp. 655-90.

Damanpour, F. (2010), "An integration of research findings of effects of firm size and market competition on product and process innovations", British Journal of Management, Vol. 21, pp. 996-1010. http://dx.doi.org/10.1111/j.1467-8551.2009.00628.x.

Felipe, C.M., Leidner, D.E., Roldán, J.L. et al. (2020), "Impact of IS capabilities on firm performance: the roles of organizational agility and industry technology intensity", Decision Sciences. http://dx.doi.org/10.1111/deci.12379.

Fornell, C. and Larcker, D.F. (1981), "Evaluating structural equation models with unobservable variables and measurement error", JMR, Journal of Marketing Research, Vol. 18, No. 3, pp. 39-50.

Gallouj, F. and Windrum, P. (2009), "Services and services innovation", Journal of Evolutionary Economics, Vol. 19, No. 2, pp. 141-8.

García-Villaverde, P.M., Elche, D. and Martínez-Pérez, A. (2020), "Understanding pioneering orientation in tourism clusters: Market dynamism and social capital", Tourism Management, Vol. 26. http://dx.doi.org/10.1016/j.tourman.2019.103966.

Hair, J.F., Sarstedt, M., Pieper, T.M. et al. (2012), "The use of partial least squares structural equation modeling in strategic management research: a review of past practices and recommendations for future applications", Long Range Planning, Vol. 45, No. 5-6, pp. 320-40. http://dx.doi.org/10.1016/j.Irp.2012.09.008.

Ittner, C.D. and Larcker, D.F. (1997), "The performance effects of process management techniques", Management Science, Vol. 43, No. 4, pp. 522-34.

Jansen, J.J.P., Van Den Bosch, F.A.J. and Volberda, H.W. (2006), "Exploratory innovation, exploitative innovation, and performance: effects of organizational antecedents and environmental moderators", Management Science, Vol. 52, pp. 1661-74.

Jayaram, J., Oke, A. and Prajogo, D. (2014), "The antecedents and consequences of product and process innovation strategy implementation in Australian manufacturing firms", International Journal of Production Research, Vol. 52, pp. 4424-39.

Kanyangi, C.A. and Gichinga, L. (2019), "Effect of innovation strategy on the organizational performance in mombasa law courts, Kenya", Strategic Journal of Business \& Change Management, Vol. 6, No. 3, pp. 517-35.

Keramati, A., Azadeh, M., Mehran-Gohar, M. et al. (2012), "Investigating the effects of information technology investment on bank performance: considering the role of environmental dynamism and strategy", International Journal of Applied Decision Sciences, Vol. 5, No. 1, pp. 32-46. http://dx.doi.org/10.1504/IJADS.2012.044945.

Klingenberg, B., Timberlake, R., Geurts, T.G. et al. (2013), "The relationship of operational innovation and financial performance: a critical perspective", International Journal of Production Economics, Vol. 142, No. 2, pp. 317-23.

Kohler, T. (2015), "Crowdsourcing-based business models: how to create and capture value", California Management Review, Vol. 57, No. 4, pp. 25-36.

Lee, L.T.S. (2011), "The effects of environmental dynamism and team strain on product innovation: The moderating role of perceived diversity climate", African Journal of Business Management, Vol. 5, pp. 8740-52.

Lumpkin, G.T., Dess, G.G. (2001). Linking two dimensions of entrepreneurial orientation to firm performance: The moderating role of environment and industry life cycle. Journal of Business Venturing 16, 429-451.

Maine, E., Lubik, S. and Garnsey, E. (2012), "Process-based vs. product-based innovation: Value creation by nanotech ventures", Technovation, Vol. 32, No. 3, pp. 179-92.

Murat Ar, I. and Baki, B. (2011), "Antecedents and performance impacts of product versus process innovation: Empirical evidence from SMEs located in Turkish science and technology parks", European Journal of Innovation Management, Vol. 14, pp. 172-206. 
Investigating the impact of process and product innovation strategies on business performance due to the mediating role of environmental dynamism using structural equations modeling

Organization for Economic Co-operation and Development - OECD (1997), Proposed Guidelines for Collecting and Interpreting Technological Innovation Data: Oslo Manual, OECD, Paris

Porter, M.E. (1985), "Technology and competitive advantage", The Journal of Business Strategy, Vol. 5, No. 3, pp. 60-78

Prajogo, D.I. (2016), "The strategic fit between innovation strategies and business environment in delivering business performance", International Journal of Production Economics, Vol. 171, pp. 241-9.

Preacher, K.J. and Leonardelli, G.J. (2003), Calculation for Sobel Test: an Interactive Calculation Tool for Mediation Tests", Vanderbilt University, Nashville, TN.

Şahin, F. and Gürbüz, S. (2020), "Entrepreneurial orientation and international performance: The moderating role of cultural intelligence", Journal of Management \& Organization, Vol. 26, No. 2, pp. 263-87. http://dx.doi.org/10.1017/jmo.2017.52.

Tao, L., Garnsey, E., Probert, D. et al. (2010), "Innovation as response to emissions legislation: revisiting the automotive catalytic converter at Johnson Matthey", $R \&$ D Management, Vol. 40, pp. 154-68.

Tenenhaus, M., Amatos, S. and Esposite Vinzi, V. (2004), “A gobal goodness of fit index for PLS structural equation modeling", in Proceeding of the XLII SIS Scientific Meeting, CLEUP, Padova, Italy, pp. 739-42.

Tripsas, M. (2008), "Customer preference discontinuities: a trigger for radical technological change", Managerial and Decision Economics, Vol. 29, pp. 79-97.

Tsai, K.H. and Yang, S.Y. (2013), "(. Firm innovativeness and business performance: The joint moderating effects of market turbulence and competition", Industrial Marketing Management, Vol. 42, pp. 127994.

Vafaei, S., Bazrkar, A. and Hajimohammadi, M. (2019), "The investigation of the relationship between sustainable supply chain management and sustainable competitive advantage according to the mediating role of innovation and sustainable process management", Brazilian Journal of Operations \& Production Management, Vol. 16, No. 4, pp. 572-80.

Wang, H. and Chen, W.R. (2010), "Is firm-specific innovation associated with greater value appropriation? The roles of environmental dynamism and technological diversity", Research Policy, Vol. 39, pp. 14154.

Weiblen, T. and Chesbrough, H.W. (2015), "Engaging with startups to enhance corporate innovation", California Management Review, Vol. 57, No. 2, pp. 66-90.

Weiss, P. (2003), "Adoption of product and process innovations in differentiated markets: the impact of competition", Review of Industrial Organization, Vol. 23, pp. 301-14.

Werts, C.E., Linn, R.L. and Joreskog, K.G. (1974), "Intra class reliability estimate: testing structural assumptions", Educational and Psychological Measurement, Vol. 34, No. 1, pp. 25-33. http://dx.doi.org/10.1177/001316447403400104.

Wetzels, M., Odekerken-Schröder, G. and Van Oppen, C. (2009), "Using PLS path modeling for accessing hierarchical construct models: guidelines and empirical illustrations", Management Information Systems Quarterly, Vol. 33, No. 1, pp. 177. http://dx.doi.org/10.2307/20650284.

Wu, L., Liu, H. and Zhang, J. (2017), "Bricolage effects on new-product development speed and creativity: the moderating role of technological turbulence", Journal of Business Research, Vol. 70, pp. 127-35.

Zeng, S., Qin, Y. and Zeng, G. (2019), "Impact of corporate environmental responsibility on investment efficiency: the moderating roles of the institutional environment and consumer environmental awareness", Sustainability, Vol. 11, pp. 4512.

Zhang, M., Qi, Y., Wang, Z. et al. (2019), "Effects of business and political ties on product innovation performance: Evidence from China and India", Tecnovation, Vol. 80, No. 81, pp. 30-9.

Zhao, Q., Tsai, P.-H. and Wang, J.-L. (2019), "Improving financial service innovation strategies for enhancing china's banking industry competitive advantage during the fintech revolution: a hybrid MCDM model", Sustainability, Vol. 11, No. 5, pp. 1419. http://dx.doi.org/10.3390/su11051419.

Zhu, X., Xiao, Z., Dong, M.C. et al. (2019), "The fit between firms' open innovation and business model for new product development speed: a contingent perspective", Tecnovation, Vol. 86, pp. 75-85.

Authors contribution: All the Authors contributed equally to this paper. 